\title{
Aplikasi Pendekatan-Pendekatan Persuasif Pada Riset Komunikasi Pemasaran: Iklan Melibatkan Penciptaan dan Penerimaan Pesan Komunikasi Persuasif Mengubah Perilaku Pembelian
}

\author{
Primadhany Kartana Putri \\ (putriprima@usm.ac.id) \\ (Staf Pengajar Jurusan Ilmu Komunikasi Universitas Semarang)
}

\begin{abstract}
The study explain how to describe and apply Persuasion Theories in Advertising is typically define as human communication that is designed to influence others by modifying their beliefs, values, or attitude. Many theories of persuasif communication are concerned with shift in attitude is a relatively enduring predisposition to respond favorably or unfavorably toward something. The reseacher presents and compares the three theories of persuasion, the Elaboration Likehood Model (ELM), Cognitive Dissonance and Attribution that explore aspects of persuasive communication which are presented or examined in several previous studies. Although protayed as theories of persuasion, each of these point of viewpoints can be appiled to a wide variety communication messages delivered by marketers to influence and change consumer attitudes. The relevance theories bridges communication and cognition and, as such, provides a solid foundation for further research on persuasion, marketing communication, and many other aspects that influence consumer behavior.
\end{abstract}

Kata Kunci : Teori persuasif, Advertising, Komunikasi persuasif.

\section{Pendahuluan}

Riset komunikasi pemasaran bertanggungjawab untuk menyediakan informasi mengenai produk atau jasa yang dimiliki kepada konsumen untuk pengambilan keputusan pembelian. Informasi tersebut harus tepat, dipercaya dan relevan. Informasi yang disampaikan haruslah mengandung pesan yang efektif dan tepat sasaran karena terkait dengan mahalnya biaya riset dan persaingan yang semakin tinggi, serta perlunya pengambilan keputusan yang benar dan tepat.

American Marketing

Association's mengemukakan salah satu fungsi pemasaran yaitu menghubungkan konsumen, pelanggan dan masyarakat dengan pemasar melalui informasiinformasi yang digunakan untuk mengidentifikasi dan menentukan peluang dan masalah pemasaran, menghasilkan, memperbaiki, dan mengevaluasi tindakan pemasaran. Fungsi pemasaran juga untuk memantau kinerja pemasaran dan meningkatkan pemahaman pemasaran sebagai proses. Pendapat tersebut menunjukkan, untuk mencapai keberhasilan pemasaran, maka pemasar harus pandai memilih dan merancang pesan persuasif melalui bauran komunikasi pemasaran seperti advertising, personal selling, direct marketing, or public relation yang tepat terhadap konsumennya.

Iklan atau advertising adalah salah satu media utama yang digunakan untuk menyampaikan pesan pemasar kepada konsumen. Diyakini iklan akan mempe ngaruhi keputusan dalam pembelian. Iklan diyakini berhubungan dengan persepsi, dan pemasaran sendiri adalah pertempuran persepsi, bukan pertempuran produk (Al Ries, dalam Wibowo, Elisawati \& Kartajaya, 1996). Pemasar harus mengetahui dan memahami faktor-faktor yang berpengaruh dalam masalah riset periklanan, yang salah satunya adalah 
perilaku konsumen. Pemahaman yang baik terhadap perilaku konsumen akan memudahkan pemasar untuk memperkirakan respon perilaku konsumen terhadap program komunikasi pemasaran tertentu.

Untuk mencapai pengambilan keputusan yang tidak menimbulkan keraguan sangatlah sulit. Pemasar juga sering melakukan tindakan seperti:

Menekankan informasi pada harapan yang akan diperoleh dari pembelian produk; (2) Mengupayakan terjadinya perubahan sikap; dan (3) Tugas pemasar dalam membentuk perilaku pengambilan keputusan konsumen adalah melakukan pendekatan komunikasi persuasif kepada konsumen baik secara rasional maupun emosional. Dengan cara rasional, aspek yang dipengaruhi berupa ide, maka komponen kognitif pada diri konsumen dapat dipengaruhi. Persuasi yang dilakukan secara emosional, biasanya menyentuh aspek kognitif, afektif, dan konatif yaitu hal yang berkaitan dengan cara berfikir dan kehidupan emosional seseorang. Melalui cara berfikir dan emosional, aspek simpati dan empati seseorang dapat digugah.

Persuasi adalah proses komunikasi yang mengajak atau membujuk orang lain dengan tujuan mengubah sikap, keyakinan dan pendapat sesuai keinginan komunikator. Pada definisi ini 'ajakan' atau 'bujukan' adalah tanpa unsur ancaman/ paksaan, (Burgon \& Huffner, 2002). Persuasi dalam esensi komunikasi pemasaran adalah upaya yang dilakukan komunikator pemasaran untuk meyakinkan konsumen untuk membeli suatu produk atau jasa. Para pemasar produk/jasa saling berlomba-lomba mensinergikan bauran komunikasi pemasaran untuk menarik intelektualitas konsumen dan perasaan mereka. Upaya tersebut juga bertujuan untuk menciptakan citra yang diinginkan bagi merek mereka, agar konsumen suatu saat membelinya.
Artikel ini menjelaskan dan mengidentifikasikan pendekatan pendekatan persuasif pada studi ilmu komunikasi yang terdiri dari Elaboration Likehood Model, Attribution, dan Cognitive Dissonance yang diaplikasikan pada riset komunikasi pemasaran melalui hasil-hasil penelitian yang telah diuji sebelumnya, dan dalam hal ini adalah pesan iklan yang mempengaruhi perilaku pembelian konsumen. Adapun teknik penelitian-penelitian yang digunakan untuk menganalisis masalah persuasi yang dikaji yaitu menggunakan metode kualitatif pada analisis pendekatan Elaboration Likehood Model, dan kuantitatif pada pendekatan Attribution dan Cognitif Dissonance. Penulis bermaksud menarik benang merah dengan cara membandingkan, menjelaskan dan menarik kesimpulan sesuai dengan landasan-landasan teori dan hasil-hasil penelitian sebelumnya.

Sejak tahun 1980-an, perusahaanperusahaan di negara maju mulai bergerak menuju proses komunikasi pemasaran, yang mencakup upaya koordinasi dari berbagai elemen promosi dan kegiatan pemasaran, (Fawcett, 1993 dalam Morrisan, 2010: 7). Komunikasi pemasaran adalah aktivitas yang berusaha menyebarkan informasi, mempengaruhi dan membujuk atau meningkatkan pesan sasaran atas perusahaan dan produknya agar bersedia menerima, membeli loyal pada produk yang ditawarkan perusahaan yang bersangkutan (Saladin, 2001: 123). Aktifitas ini menuntut agar setiap pesan yang keluar harus berasal dari sumber yang sama sehingga segala informasi yang diumumkan perusahaan memiliki kesamaan tema serta positioning yang sama di mata konsumen.

Duncan dan Moriarty mengakatan bahwa seluruh pesan yang disampaikan dan diterima secara konsisten dalam upaya untuk menciptakan persepsi yang utuh diantara pelanggan dan pihak terkait lainnya. Hal ini memerlukan kesatuan atau 
integrasi berbagai pesan komunikasi pemasaran serta integrasi fungsi berbagai fasilitator promosi. Fasilitator promosi biasanya berfungsi mengembangkan dan melaksanakan program komunikasi pemasaran terpadu, misalnya adalah biro iklan.

Enam instrumen dasar yang digunakan untuk mencapai tujuan komunikasi pemasarn perusahaan disebut bauran promosi, meliputi:

Iklan, yaitu setiap bentuk komunikasi nonpersonal mengenai suatu organisasi, produk/jasa yang dibayar oleh sponsor yang diketahui. Pemasaran langsung, yaitu upaya pemasar untuk berkomunikasi langsung dengan calon konsumen sasaran dengan maksud untuk menimbulkan tanggapan dan/transaksi penjualan. Pemasaran interaktif, yaitu komunikasi dengan konsumen secara interaktif melalui media massa, khususnya internet. Promosi penjualan, yaitu promosi penjualan yang berorientasi kepada konsumen ditujukan kepada pengguna atau pemakai akhir suatu barang dan jasa yang mencakup pemberian kupon, sampel produl, potongan harga, undian berhadiah, dan lain-lain.

Hubungan masyarakat, yaitu merencanakan dan mendistribusikan informasi secara sistematis dalam upaya untuk mengontrol dan mengelola citra serta publisitas yang diterimanya, (Duncan dan Moriarty, 1995).

Komunikasi pemasaran pada dasarnya bertujuan menyampaikan informasi produk maupun jasa berdasarkan pemenuhan dan kepuasan kebutuhan serta keinginan konsumen yang dituju. Pemasar memahami perilaku dan mengenal konsumen, karena dalam hal ini bukanlah pekerjaan yang sederhana. Konsumen mungkin menyatakan akan membeli produk, namun tiba-tiba saja mereka membatalkan rencananya. Hal ini diduga disebabkan konsumen tidak terlalu yakin dengan alasan atau motivasi mereka sendiri untuk membeli suatu produk sehingga mereka mengubah pikiran mereka pada menit-menit terkahir. Tantangan terbesar pemasar adalah bagaimana mempengaruhi perilaku konsumen agar dapat mendukung produk atau jasa yang ditawarkan kepada mereka. Tujuan terpenting dari setiap aktifitas komunikasi pemasaran adalah mempengaruhi konsumen untuk membeli.

$$
\text { Perilaku konsumen, dalam }
$$

pemasar produk maupun jasa harus memahami perilaku konsumennya. Tidak adanya pemahaman terhadap motivasi, kebutuhan dan preferensi konsumen merupakan sumber kegagalan terbesar pemasaran. Pemasar perlu mengetahui kebutuhan spesifik konsumen yang dipuaskannya, dan bagaimana menerjemahkan kebutuhan itu ke dalam kriteria pembelian.

Perilaku konusmen merupakan tindakan yang langsung terlibat dalam mendapatkan, mengkonsumsi, dan menghabiskan produk dan jasa, termasuk proses keputusan yang mendahului dan menyusuli tindakan ( Engel, Blackwell dan Minniard, 2002: 3). Konsumen akan berespons terhadap suatu produk maupun jasa asalkan produk maupun jasa itu didukung dengan efektifitas komunikasi pemasaran yang memadai. Berikut model perilaku konsumen. Model perilaku konsumen menjelasakan mengenai proses keputusan pembelian konsumen. Dalam memutuskan untuk melakukan pembelian, konsumen dipengaruhi oleh stimulus yang diterima konsumen melalui faktor eksternal diantaranya; pemasaran, ekonomi, teknologi, politik, budaya, dan faktor internal diantaranya; faktor psikologi dan karakteristik konsumen. 


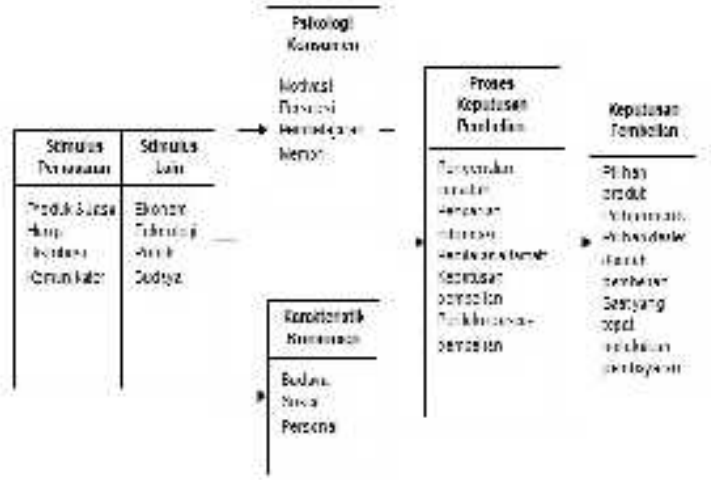

Studi perilaku konsumen banyak dilakukan oleh pemasar, kelompok akademisi, dan lembaga riset pemasaran untuk pemecahan masalah konsumen.

Penerimaan dan Penciptaan Pesan Komunikasi Persuasif menjadi Informasi yang dapat Mempengaruhi Perilaku Pembelian. Komunikasi adalah jalur yang mengubungkan kita di dunia, dan sebagai sarana individu-individu menampilkan kesan, mengekspresikan diri, mempengaruhi orang lain, dan mengorbankan diri individu itu sendiri, (Stewart dan Ruben, 2013: 17). Melalui pesan komunikasi dapat diartikan bahwa individu sedang mengalami proses belajar tentang dunia dan orang lain, menjadi siapa, dihibur, dibujuk, bergurau, ditipu, atau diberi informasi.

Dalam konteks pemasaran, melalui pesan komunikasi para pemasar berusaha membangun hubungan dengan para konsumennya. Mereka saling berkompetisi dengan kompetitor produk atau jasa yang sama dalam menciptakan pesan komunikasi yang dikemas dan diinformasikan pada sebuah iklan. Informasi yang disampaikan pasti melibatkan bahasa verbal dalam bentuk ucapan, tulisan, atau bahasa non-verbal seperti penampilan, gerak tubuh, sentuhan, atau cara lainnya. Komponen-komponen tersebut merupakan bentuk persuasi meliputi dari proses komunikasi yang dapat menimbulkan perubahan sikap.

Komunikasi adalah suatu aspek kehidupan manusia yang paling mendasar, penting, dan komplek. Dalam proses komunikasi, ada lima elemen dasar yang dikemukakan oleh Harold Lasswell dengan istilah "Who Says What in Which Channel to Whom with What Effect". Kelima elemen dasar tersebut adalah Who(sumber atau komunikator), Says What (pesan), in Which Channel (Saluran), to Whom (Penerima), with What Effect (Efek atau dampak). Lima elemen dasar dari komunikasi yang dikemukakan oleh Harold Laswell di atas akan bisa membantu para komunikator dalam menjalankan tugas mulianya, (Tubbs,S.L dan S.Moss: 1996).

Berhasil tidaknya suatu komunikasi tergantung dari kelima elemen dasar tersebut. Bagaimana komunikator bisa mempengaruhi komunikannya, sehingga bisa bertindak sesuai dengan apa yang diharapkan oleh komunikator, bahkan bisa merubah sikap dan perilaku dari komunikan tersebut. Namun, komunikator, pesan, saluran yang bagaimana yang akan bisa merubah sikap dan perilaku komunikan.

Dalam perspektif komunikasi, kita mengenal adanya komunikasi persuasif, yaitu komunikasi yang bersifat mempengaruhi audience atau komunikannya, sehingga bertindak sesuai dengan apa yang diharapkan oleh komunikator. Menurut K. Andeerson, komunikasi persuasif didefinisikan sebagai perilaku komunikasi yang mempunyai tujuan mengubah keyakinan, sikap atau perilaku individu atau kelompok lain melalui transmisi beberapa pesan.

Persuasi dalam Kamus Besar

Bahasa Indonesia berarti bersifat membujuk secara halus (supaya menjadi yakin). Dalam sudut pandang ilmu komunikasi, persuasi cenderung diistilahkan dengan sebutan komunikasi persuasif. Komunikasi persuasif bertujuan untuk mengubah sikap, pendapat, atau perilaku seseorang. Komunikasi persuasif harus dilakukan dengan halus, luwes, yang mengandung sifat-sifat manusiawi. Agar komunikasi persuasif itu mencapai tujuan 
dan sasarannya, maka perlu dilakukan perencanaan yang matang. Perencanaan yang dilakukan berdasarkan komponenkomponen komunikasi yaitu komunikator, pesan, media, dan komunikan.

Pendekatan komunikasi persuasif yang efektif menurut Burgon dan Huffner (2002) :

1. Pendekatan berdasarkan bukti, yaitu mengungkapkan data atau fakta yang terjadi sebaga bukti argumentatif agar berkesan lebih kuat terhadap ajakan.

2. Pendekatan berdasarkan ketakutan, yaitu menggunakan fenomena yang menakutkan bagi audience atau komunikator dengan tujuan mengajak mereka menuruti pesan yang diberikan komunikator.

3. Pendekatan berdasarkan humor, yaitu menggunakan humor atau fantasi yang bersifat lucu dengan tujuan memudahkan masyarakat mengingat pesan karena mempunyai efek emosi yang positif.

4. Pendekatan berdasarkan diksi, yaitu menggunakan pilihan kata yang mudah diingat (memorable) oleh komunikan dengan tujuan membuat efek emosi positif atau negative.

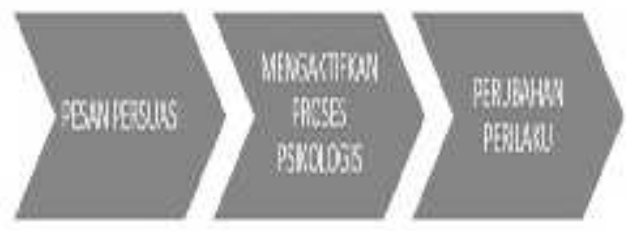

Gambar diatas menjelaskan bagaimana proses pesan persuasi mengubah perilaku seseorang. Pesan persuasi merupakan serangakan pesan informasi (stimuli) yang masuk dan diterima oleh seseorang melalui pengaktifan proses psikologis yang melibatkan tiga komponen sikap meliputi: kognitif, afektif dan konatif yang mencipatakan perilaku seseorang tersebut. Pada studi perilaku konsumen, model ini mengilustrasikan awalnya pesan persuasi merupakan stimuli pesan iklan yang dibangun oleh pemasar produk. Pemasar didalam menulis pesan komunikasi iklan yang bersifat persuasif ini dibuat untuk meyakinkan dari pihak-pihak yang berhubungan dengan produk maupun jasa yang ditawarkan. Komponen adalah pemahaman, pengetahuan, penilaian dan kepercayaan konsumen tentang informasi produk yang didapatkan dari proses berpikir.

Komponen afektif kadarnya lebih tinggi daripada kognitif. Setelah mengetahui informasi produk yang diterimanya, konsumen diharapkan dapat merasakannya. Proses ini terkait dengan perasaaan emosional konsumen terhadap produk. Komponen konatif adalah komponen ketiga dari sikap yang menggambarkan kecenderungan konsumen untuk melakukan tindakan atau mengungkapkan keinginan membeli dari seorang konsumen. Dengan demikian, dalam menciptakan sebuah pesan iklan produk maupun jasa, pesan-pesan persuasif yang efektif haruslah dirancang sedemikian rupa. Rancangan pesan tersebut antara lain fokus pada penerima, sehingga pesan yang disampaikan dapat sesuai dengan tujuan. Menulis pesan persuasif sangatlah penting dalam pemasaran, karena setiap hari pemasar harus mengirimkan pesan-pesan dengan nada yang meyakinkan kepada konsumen.

Pada dasarnya iklan merupakan salah satu bauran komunikasi pemasaran yang memiliki suatu kekuatan yang mampu menggiring para konsumen untuk bertindak dan mengambil suatu keputusan dalam membeli suatu produk atau jasa yang ditawarkan. Kekuatannya terletak pada pesan yang disampaikan dan sejauh mana pesan tersebut melekat dan mudah diingat oleh konsumen. Hal tersebut akan sangat tergantung pada sejauh mana iklan mampu mengaplikasikan komunikasi persuasif dalam mengunggah minat dan keinginan konsumen. Dalam contoh iklan, banyak para pemasar yang memberikan efek warna gambar yang memikat, tagline, melibatkan endorser, bentuk tulisan, slogan dan lain-lain. 
Artikel ini mencoba menjelaskan mengenai pentingnya aspek persuasif pada perancangan pesan komunikasi, khsusunya dampak dari penerimaan dan penciptaan pesan iklan terkait dengan proses perubahan perilaku konsumen. Tujuan dari perancangan pesan komunikasi persuasif pada iklan diantaranya:

1) Memberi pengetahuan dan pemahaman kepada konsumen

2) Mengajak konsumen agar membeli produk tersebut

3) Mendukung terjadinya penjualan

4) Mengenalkan produk melalui kalimat yang singkat dan jelas, bahasa yang mudah dipahami, serta tulisan dan gambar yang menarik perhatian konsumen.

\section{Pembahasan}

Terdapat tiga jenis pendekatan persuasif yang dikaji dalam studi ilmu komunikasi dan dijelaskan pada artikel ini meliputi, Ellaboration Likehood Model, Cognitive Dissonance, dan Atribution.

Pada sub pembahasan, penulis akan sedikit menjelaskan dan memberi tanggapan mengenai kontribusi pendekatan-pendekatan persuasif yang terdiri dari Ellaboration Likehood Model, Attribution dan Cognitive Dissonance yang diaplikasikan dalam studi komunikasi pemasaran khususnya, pada pengembangan pesan iklan dan pengaruhnya pada perubahan perilaku pembelian konsumen pada penelitianpenelitian yang telah dilakukan sebelumnya. Pada penelitian mengenai analisis persuasif, ketiga pendekatan ini dapat didentifikasikan dengan menggunakan teknik analisis kulitatif dan kuantitatif. Metode yang dapat digunakan anatara lain metode deskriptif, eksploratif, dan eksplanatori.

\section{Ellaboration Likehood Model (ELM)}

Teori ini dikemukakan dan dikembangkan oleh ahli psikologi sosial yaitu Richard Petty dan John Cacioppo, dan telah menjadi teori persuasi paling populer saat ini. ELM merupakan salah satu teori komunikasi yang membahas bagian model perubahan sikap dalam diri seseorang ketika individu menerima suatu pesan. Asumsi yang dikemukakan oleh Petty dan Cacioppo bahwa pada awalnya setiap individu berusaha memiliki sikap yang tepat terhadap kondisi yang dihadapi, akan tetapi setiap individu sesungguhnya selalu berusaha merasionalisasi kondisi yang dihadapinya. ELM mengasumsikan bahwa argumentasi-argumentasi yang kuat akan selalu berhasil atau paling tidak akan masuk ke dalam rute peripheral dimana jika rute central menyangkut perubahan kebiasaan, rute peripheral lebih kepada perubahan sikap saja/untuk sementara waktu.

Model ELM ini merupakan teori persuasi yang dapat dijadikan acuan bagaimana mempengaruhi sikap dan perilaku seseorang dalam merespons suatu pesan Mereka juga menemukan pola kognisi penerimaan pesan dalam proses terpersuasi atau kemungkinan elaborasi tergantung pada cara seseorang mengolah dan memproses pesan yang diterima. ELM ini memiliki dua rute bagaimana penerima dapat menerima pesan yang disampaikan, yaitu diantaranya rute central route dan rute peripheral.

Rute Central, yaitu elaborasi atau pemikiran kritis. Dalam hal ini, seseorang dalam mengolah suatu pesan akan distimulus suatu informasi akan mendiskursuskan terlebih dahulu alam aktifitas mentalnya, memilih, melakukan imajiner dengan mempertimbangkan keuntungan dan kerugian dari informasi tersebut. Rute Peripheral, yaitu suatu kecenderungan kognitif dimana penerimaan atau penolakan suatu pesan lebih ditekankan pada kredibilitas pengirim pesan, reaksi lingkungan, atau terpengaruh oleh faktor-faktor lain di luar argumentasi, (Petty dan Cacioppo, 1996).

Pendekatan ELM telah digunakan oleh para peneliti akademisi dalam studi komunikasi pemasaran. Ketto dan Murti, dalam penelitiannya berjudul 'Proses Pengambilan Keputusan Konsumen dalam 
Membeli produk Sepatu Olah Raga mengemukakan Proses pengambilan keputusan dalam membeli produk sepatu New Balance dipengaruhi oleh sumber informasi, pesan visual warna, bentuk, dan logo yang ditampilkan pada produk sepatu New Balance. Penelitian ini dilakukan pada kalangan mahasiswa yang berada di daerah Yogyakarta, karena mahasiswa telah banyak membeli dan menggunakan produk sepatu New Balance.

Obyek penelitian adalah pesan produk sepatu New Balance yang dikemas dan disampaikan melalui media katalog, internet (Google, Facebook dan Twitter) dan orang lain. Pengirim pesan merupakan pihak pemasar New Balance, dan penerima pesan adalah mahasiswa/i Universitas Atma Jaya Yogyakarta, Universitas Gadjah Mada Yogyakarta, Universitas Sanata Dharma, dan Universitas Pembangunan Nasional yang ingin membeli produknya. Metode penelitian yang digunakan adalah metode deskriptif kualitatif, yaitu dengan memaparkan hasil penelitian yang ditemukan di lapangan menjadi sebuah deskripsi. Teknik pengumpulan data yang digunakan adalah dengan melakukan wawancara mendalam.

Berdasarkan hasil wawancara diatas dari delapan narasumber kebanyakan dari mereka memilih media Facebook dan Twitter sebagai tempat untuk mencari informasi mengenai produk sepatu New Balance, selebihnya memilih mencari dan menerima informasi dari teman, saudara dan katalog. Hasil analisis menunjukkan efek setelah menerima pesan atau informasi yang disampaikan melalui media Facebook, Twitter, katalog dan teman. Analisis yang ditemukan adalah pesan dikemas dan disampaikan melalui beberapa media perantara yaitu media internet dan media katalog. Efek setelah menerima pesan atau informasi yang disampaikan melalui media Facebook, Twitter, katalog dan teman telah mempengaruhi narasumber untuk mempertimbangkan pada saat ingin melakukan pembelian. Efek lain yang mempengaruhi adalah daya tarik visual yang ditampilkan oleh Produk Sepatu New Balance yang ditampilkan melalui Facebook, Twitter, dan katalog, terutama melalui pesan warna. Ketertarikan akan warna yang unik awalnya membuat narasumber tidak lagi melakukan pencarian informasi dan menganalisis pesan atau informasi produk new balance, melainkan langsung melakukan pembelian. Intinya adalah pada penelitian tersebut terdapat jalur ELM yang dilalui oleh narasumber saat melakukan pembelian produk New Balance. Mereka memutuskan untuk membeli merek sepatu tersebut karena ketertarikan pada warna dan bentuk yang unik. Secara langsung narasumber tergolong pada jalur peripheral, dan akan tetapi mereka tetap termotivasi untuk terus melakukan pencarian informasi akan merek produk sepatu New Balance. Dalam rute peripheral maka penerima terlibat dalam elaborasi yang rendah. Elaborasi yang dimaksud adalah "sejauh mana seseorang dengan hati-hati berfikir tentang issuerelevantargument yang terkandung didalam suatu komunikasi persuasi dengan pendapat yang rasional. Dengan demikian meskipun narasumber tergolong pada konsumen dengan keterlibatan rendah, dalam melakukan dan komunikasi pemasaran, pemasar pada produk New Balance dituntut untuk memiliki kredibilitas yang tinggi dalam mengemas dan mengirim pesan melalui bauran promosi yang efektif, serta memahami faktor-fakto lingkungan lain yang mempengarahui keputusan pembelian.

Sejalan dengan pemikiran Peety dan Cacioppo, bahwa teori persuasi ini mencoba untuk memprediksi kapan serta bagaimana seseorang akan dan tidak akan terbujuk oleh pesan, (Littlejohn, 2009: 108). Hasil pada studi produk sepatu New Balance menunjukkan, narasumber sebagai konsumen produk sepatu tersebut mulai terbujuk untuk melakukan 
pembelian sepatu setelah diterpa oleh pesan-pesan iklan yang menampilkan desain menarik dan penuh variasi warna melalui katalog dan media sosial seperti Facebook dan Twitter. Ketika konsumen mengolah pesan mengenai produk New Balance melalui rute peripheral, mereka dianggap akan sangat kurang kritis. Kemungkinan yang terjadi adalah, pada saat itu mungkin mereka sangat mudah terbujuk untuk melakukan pembelian dikarenakan ada rangsangan pesan warna yang meanrik pada iklan New Balance.

$$
\text { Peety dan Cacioppo juga }
$$

menegaskan bahwa perubahan perilaku pembelian konsumen pada rute peipheral tersebut dapat terjadi. Kemungkinan tersebut dapat berbentuk perubahan elaborasi yang terjadi dalam diri konsumen, apakah akan tetap melalui rute peripheral, atau berubah melalui rute central, atau bahkan mengalami kedua rute tersebut, yaitu dari rute pheriperal mengalami peningkatan menuju rute central. Kondisi perubahan tersebut dapat terjadi karena mengingat kecenderungan elaborasi adalah sebuah variabel, konsumen mungkin akan menggunakan kedua rute tersebut sampai taraf tertentu, bergantung pada seberapa besar keterkaitan produk New Balance tersebut terhadap konsumen. Awalnya konsumen terbujuk untuk membeli karena ada rangsangan pesan yang dianggap menarik perhatian, akan tetapi semakin tinggi tuntutan kesesuaian antara kebutuhan dan keinginan konsumen dengan produk maupun jasa yang akan dibelii, maka semakin mempengaruhi tingkat pencarian dan pengevaluasian informasi mengenai produk maupun jasa tersebut. Pada studi komunikasi pemasaran, pendekatan ELM sangat cocok digunakan sebagai landasan penelitian komunikasi pemasaran. Melalui pendekatan ini, peneliti dapat mengetaui bagaimana proses pesan persuasi yang dilakukan dan mengukur besarnya perubahan sikap yang terjadi akibat proses tersebut. Dalam konteks periklanan, model ini menganggap keefektifan iklan dapat dipengaruhi oleh salah satu dari dua rute persuasi yang berbeda, yaitu rute peripheral dan rute central.

Studi pada penelitian konsumen New Balance ini awalnya mengidentifikasikan dan menjelaskan bahwa konsumen berada di rute peripheral. Hasil penelitian memperlihatkan narasumber menggunakan rute pheriperal. Ketika narasumber telah menerima pesan atau informasi mengenai produk sepatu New Balance melalui teman (adik), narasumber secara langsung tertarik oleh pesan yang disampaikan, sehingga narasumber melakukan pencarian informasi melalui media katalog yang hanya menampilkan pesan mengenai warna, bentuk, gambar dari setiap produknya, dan ukuran sepatu yang ditawarkan.

Ketto dan Murti mengemukaan bahwa para mahasiswa tetap termotivasi untuk melakukan pencarian informasi akan produk sepatu New Balance. Hal ini memperlihatkan bahwa konsumen kembali masuk pada rute central. Mereka melakukan pencarian informasi melalui beberapa media yaitu Facebook, Twitter, katalog, dan teman. Setelah informasi tersebut diterima, narasumber mengevaluasi dan menganalisis pesan atau informasi tersebut dari berbagai sudut pandang dengan kemampuan yang dimiliki yaitu dengan mendatangi langsung tempat penjualan untuk menanyakan harga dan melihat secara detail memperhatikan secara detail kualitas, keunggulan, features, warna, bentuk, dan atribut-atribut yang ditampilkan pada produk sepatunya, mempertimbangkan produk sepatu ini telah sesuai dengan kebutuhan dan keinginan, menanyakan kepada teman yang lebih dulu menggunakan produk sepatu New Balance, dan membandingkan informasi yang telah diterima dengan informasi lainnya. Setelah menerima pesan mereka semakin yakin dan secara langsung melakukan 
(http://ejournal.uajy.ac.id/6554/1/jurnal\%2 0skripsi.pdf)

\section{Attribution}

Teori atribusi (attribution) didasarkan pada gagasan bahwa kita termotivasi untuk atribut kausalitas untuk peristiwa di sekitar kita. Teori atribusi bermula dengan gagasan bahwa setiap individu mencoba untuk memahami perilaku mereka sendiri dan orang lain dengan mengamati bagaimana sesungguhnya setiap individu berperilaku, (Littlejohn, 2009: 101). Penemu teori atribusi, Firtz Heider menyebutkan beberapa atribusi kausal yang biasa dibuat setiap orang.

Heider menyebutkan beberapa atribusi yang mendorong orang memiliki tingkah laku diantaranya:

1) penyebab situasional, yaitu orang dipengaruhi oleh lingkungannya

2) adanya pengaruh personal, yaitu ingin mempengaruhi sesuatu secara pribadi 3) memiliki kemampuan, yaitu mampu melakukan sesuatu

4) adanya usaha, yaitu mencoba melakukan sesuatu

5) memiliki keinginan, yaitu ingin melakukan sesuatu

6) adanya perasaan, yaitu perasaan menyukai sesuatu

7) rasa memiliki, yaitu ingin memiliki sesuatu

8) kewajiban, yaitu perasaan harus melakukan sesuatu

9) diperkenankan, yaitu diperbolehkan melakukan sesuatu

Teori atribusi psikologi pada dasarnya menjelaskan keadaan rasional (berpikir dengan menggunakan nalar berdasarkan fakta yang nyata untuk mencari sebuah kebenaran) yang ada pada diri seseorang. Manusia sebagai manusia sosial tidak dapat dipisahkan dari lingkungan sekitar di mana mereka tinggal dan pada saat mereka berada di lingkungan, secara otomatis mereka akan memperhatikan dan mengamati setiap perilaku dari masing - masing individu.
Studi komunikasi pemasaran dengan menggunakan pendekatan atribusi juga pernah dilakukan oleh beberapa peneliti. Ellyada dan Wiratmojo dalam peneltiannya yang berjudul 'Pengaruh Daya Tarik Brand Ambassador dan Daya Tarik Jingle Iklan Versi Iklan Televisi terhadap Keputusan pembelian Magnum Classic di Kalangan Mahasiswa/i ISI Yogyakarta'. Mereka menjelaskan bahwa salah satu strategi pemasaran yang dilakukan oleh perusahaan adalah menggunakan brand ambassador pada suatu iklan yang disajikan. Pemilihan brand ambassador dilatarbelakangi oleh citra positif yang dibawa oleh brand ambassador. Brand ambassador dipilih oleh perusahaan sebagai simbolisasi atau penanda untuk mewakili keinginan dan kebutuhan dari calon konsumen. Daya tarik brand ambassador Magnum Classic yaitu Olla Ramlan dapat dikatakan telah berhasil menarik perhatian konsumen terkait dengan keputusan pembelian Magnum Classic, dengan begitu keberhasilan Olla Ramlan sebagai brand ambassador juga tidak terlepas dari peran produk itu sendiri yaitu Magnum Classic.

Tujuan penelitian tersebut adalah menganalisis pesan iklan, diantaranya pengaruh daya tarik brand ambassador sebagai variabel bebas pertama, dan jingle pada iklan televisi Magnum Classic sebagai variabel bebas kedua terhadap keputusan pembelian di kalangan mahasiswa/i ISI, Yogyakarta sebagai variabel terikatnya.

Berdasarkan tujuan penelitian, maka pada diangkat sebuah hipotesis yaitu:

1. H1: adalah adanya pengaruh antara daya tarik brand ambassador (X1) dengan keputusan pembelian (Y)

2. H2: adanya pengaruh antara daya tarik jingle (X2) dengan keputusan pembelian (Y)

Jenis penelitian ini menggunakan metode kuantitatif deskriptif dengan menggunakan instrumen kuesioner. Analisis data yang 
digunakan menggunakan uji regresi dengan alat bantu SPSS 20. Hasil penelitian menunjukkan variabel daya tarik brand ambassador memiliki nilai signifikasi sebesar $0,01(0,01<0,05)$ yang artinya variabel daya tarik pengaruh terhadap keputusan pembelian. Daya tarik brand ambassador terhadap keputusan pembelian sebesar $r \quad(0,906)$, jika dikuadratkan nilai $r$ yang menunjukkan kontribusi sebesar $82,2 \%$ terhadap daya tarik brand, dan sisanya dipengaruhi oleh faktor lainnya. Variabel daya tarik jingle iklan memiliki nilai signifikasi sebesar $0,19(0,19<0,05)$ yang artinya variabel ini memiliki pengaruh terhadap keputusan pembelian. Daya tarik jingle iklan terhadap keputusan pembelian sebesar $r(0,607)$, jika dikuadratkan nilai $r$ yang menunjukkan yang menunjukkan kontribusi sebesar 36,8\%, (Ellyada dan Wiratmojo: 2013).

Salah satu teori yang digunakan dalam penelitian ini yaitu teori atribusi sosial. Teori atribusi yang condong ke arah psikologis melihat sebagai suatu tindakan yang berhubungan dengan emosional yang dapat dihubungkan dengan perilaku konsumen, di mana emosional yang ada dalam diri seseorang ketika melihat sesuatu yang baru akan merasa tertarik walaupun tidak sesuai dengan yang diharapkannya. Olla Ramlan diduga mampu mewakili orang - orang yang sibuk terutama wanita pekerja untuk tetap dapat menikmati kebahagiaan, salah satunya dengan mengkonsumsi es krim dengan varian cokelat dan vanilla yang banyak digemari masyarakat. Mahasiswa/i tergolong pada individu yang cukup memiliki kesibukan dalam aktifitas perkulihan di lingkungan kampus, disamping itu mereka cenderung menjadi sosok individu yang pro aktif dalam melakukan suatu pekerjaan yang bersifat non-akademik di luar jam perkuliahan. Iklan yang kreatif sangat dibutuhkan dalam upaya menarik perhatian calon konsumen dan salah satu sisi kreatif yang dilakukan oleh Magnum Classic adalah dengan menggunakan artis yaitu Olla Ramlan sebagai brand ambassadornya. Hal ini dilakukan untuk menarik perhatian calon konsumen terhadap produk.

Pesan iklan pada dasarnya tidak hanya menginformasikan berbagai manfaat produk, akan tetapi juga melihat siapa yang menyampaikan atau terlibat dalam produk tersebut. Iklan tidak hanya menyampaikan apa yang menjadi manfaat produk tetapi juga melihat siapa yang menyampaikan iklan tersebut. Pesan iklan ini termasuk ke dalam publisitas positif karena menggunakan bintang iklan di dalam menyebarkan informasi kepada calon konsumen tentang manfaat produk dan dalam hal ini yang berperan adalah Olla Ramlan.

Menurut hasil pengamatan penulis, jika diikaitkan dengan pengaplikasian teori atribusi pada penelitian tersebut, maka dijelaskan bahwa atribusi yang mendorong mahasiswa/i ISI Yogyakarta memiliki tingkah laku pembelian Magnum Classic adalah atribusi penyebab situasional, yaitu dipengaruhi oleh lingkungannya dan adanya perasaan menyukai sesuatu, dalam hal ini adalah Olla Ramlan merupakan salah satu bintang idolanya, dan dianggap sebagai gambaran situasional pada diri mahasiswa/i ISI Yogyakarta. Atribusi rasa ingin berusaha yaitu dengan adanya usaha, maka ia akan mencoba melakukan sesuatu. Upaya tersebut adalah bagaimana mereka memikirkan, mencapai dan merasakan dampak setelah mengkonsumsi es krim Magnum Classic. Untuk memenuhi kebutuhannya, mereka mencoba merasakan kenikmatan es krim yang diduga mampu menciptakan rasa kebahagiaan disela-sela kesibukan dan menghilangkan ketegangan pikiran.

\section{Cognitive Dissonance}

Teori cognitive dissonance dikemukakan oleh Festinger yang menjelaskan bahwa cognitive dissonance adalah diskrepansi atau kesenjangan yang 
terjadi anatar dua elemen kognitif yang tidak konsisten, menciptakan ketidaknyamanan psikologis. Teori ini mengidentifikasikan bahwa kognitif menunjuk pada setiap bentuk pengetahuan, opini, keyakinan atau perasaan mengenai diri seseorang atau lingkungan seseorang. Elemen-elemen kognitif ini berhubungan dengan hal-hal nyata atau pengalaman sehari-hari di lingkungan dan hal-hal yang terdapat dalam dunia psikologis seseorang. Menurut Festinger, terdapat dua elemen hubungan cognitive :

1. Hubungan relevan (relevant), yaitu hubungan yang berkaitan antara satu dengan yang lainnya. Hubungan ini terdiri dari dua macam yaitu disonan (jika dari kedua elemen kognitif, satu elemen diikuti dengan penyangkalan (observe) dari yang lainnya)dan konsonan (jika terjadi kedua elemen bersifat relevan dan tidak disonan, dimana satu kognisi diikuti secara selaras). 2. Hubungan tidak relevan (irrelevant), yaitu tidak adanya kaitan antara dua elemen kognitif.

Ginting dan Meiyanto dalam penelitiannya yang berjudul 'Postpurchase Dissonance Observed from Consumer's Intention as an Innovator, Ability as an Opinion Leaders and Level of Creativity' menjelaskan mengenai keraguan dan kecemasan yang dialami oleh seorang konsumen setelah melakukan suatu keputusan yang sulit dan relatif permanen (postpurchase dissonance). Postpurchase dissonance umumnya terjadi pada produk dengan kategori high involvement, yaitu yang memang keterlibatan konsumen pada produk itu sangat tinggi (Hill \& O'Sullivan, 1999). Produk yang dipilih adalah produk elektronik. Subyek dalam penelitian ini adalah mereka yang melakukan pembelian laptop, personal computer, handphone communicator, TV, video/kamera digital.

Ada beberapa upaya untuk menyampaikan sejumlah pesan mengenai produk-produk tersebut dari pemasar kepada konsumen yang disebutkan oleh peneliti yaitu salah satunya adalah melalui iklan. Menurut mereka, iklan diyakini akan mempengaruhi keputusan dalam pembelian. Semakin pemasar berhasil mengubah persepsi konsumen maka semakin besar kemungkinan konsumen memilih produknya. Untuk mencapai pengambilan keputusan yang tidak menimbulkan keraguan sangatlah sulit. Pemasar juga sering melakukan tindakan seperti: (1). Menekankan informasi pada harapan yang akan diperoleh dari pembelian produk; (2). Mengupayakan terjadinya perubahan sikap; dan (3). Memberikan janji-janji kepada calon konsumen dalam bentuk bonus, diskon dan sebagainya (Loudon \& Bitta, 1993), serta (4). Informasi yang diberikan secara umum hanya memuat hal-hal yang bersifat positif dan menyenangkan, jarang memuat sisi negatif dari produknya.

Di dalam studi ini cognitive dissonance cenderung ditujukan pada keraguan pada saat konsumen melakukan pasca pembelian. Metode penelitian ini adalah model ex post facto. Penelitian ini melibatkan subyek sebanyak 120 orang konsumen dengan metode pengambilan sampel penelitian adalah Convenient sampling. Adapun skala dan alat tes yang digunakan yaitu: skala postpurchase dissonance, skala kecenderungan sebagai inovator, dan skala kemampuan sebagai opinion leader.

Analisa data yang digunakan dalam penelitian ini adalah Analisa Regresi Berganda untuk melihat sejauh mana kecenderungan sebagai inovator, Kemampuan sebagai opinion leaders dan tingkat kreativitas mampu sebagai Variabel prediktor dari postpurchase dissonance yang dalam penelitian ini menjadi Variabel kriteria. Hasil analisis mengidentifikasikan bahwa ketiga prediktor yang dikemukakan memiliki karakteristik yang sama yaitu kondisi kepribadian, kecemasan serta emosi yang mempengaruhi keputusan postpurchase dissonance konsumen (hipotesa hiterima 
dengan nilai uji $\mathrm{F}=4.800 \mathrm{p}<0,01)$, dan hanya berkontribusi sebesar 9\%, (Ginting dan Meiyanto, 2010: 189-202).

Ketersediaan informasi iklan (penyebaran informasi melalui media cetak dan televisi) yang semuanya itu digolongkan dalam faktor eksternal dari postpurchase dissonance, yang diduga memiliki kontribusi sebesar $91 \%$ sebagai faktor yang memperkuat konsumen melakukan postpurchase dissonance. Berdasarkan ketiga hasil penelitian, maka pendekatan-pendekatan persuasif sangat berkontribusi dalam perancangan dan pengembangan pesan periklanan produk maupun jasa. Fungsi periklanan itu sendiri adalah sebagai alat untuk menyampaikan pesan tentang produk atau jasa kepada konsumen sasaran. Pengetahuan dan pemahaman konsumen mengenai keberadaan produk sangatlah penting, karena hal tersebut merupakan penentu apakah konsumen yang bersangkutan akan menjatuhkan pilihan pada produk atau jasa yang ditawarkan atau tidak. Tugas pemasar adalah, bagaimana mereka mampu menciptakan atau merancang dan mengemas sebuah pesan persuasif melalui iklan. Pesan- pesan yang dirancang harus memiliki daya tarik yang mampu mengunggah minat dan keinginan konsumen, misalnya menampilkan feature atau atribut-atribut seperti slogan, warna, musik, bahasa, bentuk tulisan atau bahkan melibatkan endorser seorang selebriti atau model. Tujuannya adalah untuk menunjukkan dan menegaskan kualitas dan keunggulan daripada produk atau jasa yang ditawarkan kepada konsumen.

Pendekatan persuasif harus diaplikasikan dalam riset perilaku konsumen terkait dengan pengaruh komunikasi pemasaran, terutama iklan. Iklan selain berfungsi sebagai alat penyampaian pesan, iklan dianggap sebagai stimulus yang mempengaruhi sikap, dan pemicu sikap positif terhadap produk. Sikap merupakan bentuk dari respon atas stimulus. Konsumen melalui proses pembentukan sikap yang teridiri dari komponen kognitif, afektif, dan konatif akan mempengaruhi perilaku pembelian. Berkaitan dengan proses pembentukan sikap konsumen terhadap produk maupun jasa tersebut, maka diperlukan pengetahuan yang memadai atas karakteristik konsumen yang ditargetkan pada iklan yang bersangkutan, khusunya yang berperan besar memicu daya tarik bagi konsumen.

Dalam riset komunikasi komunikasi pemasaran terkait dengan pemahaman perilaku konsumen, dalam menciptakan sebuah pesan iklan, pemasar harus memiliki gaya pesan yang dapat mengemas pesan agar lebih menarik dan enak untuk dikonsumsi. Ellaboration Likehood Model mencoba mengidentifikasikan karakteristik konsumen berdasarkan tingkat kebutuhan dan keterlibatan konsumen terhadap produk atau jasa. Melalui riset ELM, pemasar mampu mengetahui apakah konsumen cenderung pada karakteristik kelompok pembeli yang teliti, cermat, dan memiliki rasa penasaran dan ingin tahu yang tinggi terhadap produk atau jasa yang ditawarkan, atau mereka cenderung pada kelompok pembeli yang biasa saja, tidak terlalu menuntut informasi secara detail mengenai keunggulan produk, atau hanya sebagai follower saja.

Perubahan elaborasi juga dapat terjadi pada diri konsumen. Hal tersebut dikarenakan faktor-faktor lingkungan yang mendorong konsumen untuk mencari dan menggali informasi lebih dalam mengenai produk atau jasa yang akan dipilihnya, apakah sudah benar-benar sesuai dengan kebutuhannya atau belum. Pada kasus pembelian produk atau jasa yang memerlukan biaya sangat mahal misalnya rumah, mobil, perguruan tinggi, dan lainlain. Biasanya konsumen tersebut tergolong pada kelompok keterlibatan tinggi. 
Fenomena perubahan elaborasi pada diri konsumen telah dibuktikan pada hasil penelitian pada perilaku pembelian yang dilakukan oleh mahasiswa terhadap merek sepatu New Balance. Awalnya mereka tergolong pada rute periphera. Mereka tertarik dengan merek tersebut karena informasi dari teman dan adik, dan secara langsung tertarik untuk melakukan pencarian informasi melalui media katalog yang hanya menampilkan pesan mengenai warna, bentuk, gambar dari setiap produknya, dan ukuran sepatu yang ditawarkan.

Pendekatan Attribution lebih menekankan faktor-faktor eksternal dan internal yang mempengaruhi perilaku pembelian. Sebagai contoh, pada penelitian Ellyada dan Wiratmojo, dalam membeli sebuah produk es krim, konsumen mungkin akan membandingkan antara Walls dengan merek es krim lainnya. Konsumen mungkin akan memperimbangkan pengamatan terhadap kelompok mana mengkonsumsi dan dijadikan patokan penggemar es krim tersebut. Pemasar Magnum Classic mencoba melibatkan endorser, yaitu seorang selebriti pada perancangan dan penanyangan iklan Walls Magnum guna menarik perhatian dan minat konsumen. Hasil penelitian pada ikan Walls Magnum menunjukkan bahwa atribut Olla Ramlan sebagai endorser es krim tersebut member dampak pengaruh positif bagi mahasiswa/i ISI Yogyakarta untuk melakukan pembelian. Penulis turut mengidentifikasikan bahwa fungsi keteribatan endorser Magnum Classic memberikan atribusi pengaruh personal, penyebab situasional, melakukan sesuatu dan atribusi perasaan suka.

Menurut hasil pengamatan penulis, jika diikaitkan dengan penerapan teori atribusi pada penelitian tersebut, maka dijelaskan bahwa atribusi yang mendorong mahasiswa/i ISI Yogyakarta memiliki tingkah laku pembelian Magnum Classic adalah atribusi penyebab situasional, yaitu dipengaruhi oleh lingkungannya dan adanya perasaan menyukai sesuatu, dalam hal ini adalah Olla Ramlan merupakan salah satu bintang idolanya, dan dianggap sebagai gambaran situasional pada diri mahasiswa/i ISI Yogyakarta. Atribusi rasa ingin berusaha yaitu dengan adanya usaha, maka ia akan mencoba melakukan sesuatu. Upaya tersebut adalah bagaimana mereka memikirkan, mencapai dan merasakan dampak setelah mengkonsumsi es krim Magnum Classic. Upaya memenuhi kebutuhannya, mereka mencoba merasakan kenikmatan es krim yang diduga mampu menciptakan rasa kebahagiaan disela-sela kesibukan dan menghilangkan ketegangan pikiran.

Bagi para pemasar produk maupun jasa apapun dalam mengemas iklan persuasif perlu memperhatikan komponen-komponen atau atribut-atribut baik dari internal dan eksternal yang digunakan untuk menunjukkan dan mengaskan keunggulan-keunggulan yang dimiliki produk atau jasa yang ditawarkan. Dalam memilih endorser pun pemasar harus lebih menyeleksi dan mempertimbangkan karakteriktik endorser tersebut dengan cara melakukan survey terlebih dahulu. Bagaimana prestasinya serta kontribusinya di lingkungan social masayarakat dan apakah cocok untuk dijadikan sebagai icon dari produk tersebut, serta seberapa terkenalnya endorser itu dimata masyarakat.

Dalam pengaplikasian pendekatan persuasif pada pengembangan dan pengemasan pesan iklan produt atau jasa dikaitkan dengan riset perilaku konsumen, terdapat sedikit perbedaan antara fungsi daripada pendekatan Cognitive Dissonance sedikit berbeda dengan Ellaboration Likehood Model dan Attribution. Jika Ellaboration Likehood Model dan Attribution digunakan sebagai pendekatan persuasif pada riset perilaku pembelian (calon konsumen). Pendekatan Cognitive Dissonance ini selain digunakan sebagai 
tolak ukur dalam riset perilaku pembelian, digunakan pula sebagai tolak ukur perilaku pasca pembelian, dan berkontribusi pada perancangan dan pengemasan pesan iklan produk maupun jasa. Dengan demikian dapat disimpulkan bahwa pesan iklan mengenai produk atau jasa semata-mata tidak hanya ditujukkan kepada calon konsumen, melainkan perlu pengembangan iklan bagi konsumen yang telah melakukan pasca pembelian. Penggunaan iklan tersebut bertujuan untuk memperkuat dorongan kebutuhan dan keinginan konsumen terhadap suatu produk untuk mencapai pemenuhan kepuasannya. Pemasar dalam hal ini harus tetap berupaya mengembangkan pesan iklan yang efektif dengan meningkatkan peranan media utama dan menggunakan atribusi-atribusi pesan yang memiliki daya tarik.

Sejalan dengan pemikiran Kotler, bahwa iklan sebagai pengingat (Reminding Advertising), yaitu untuk merangsang pembelian produk dan jasa kembali. Pemenuhan kepuasan kebutuhan konsumen dapat dipahami melalui pengalaman-pengalaman konsumen serta faktor-faktor lingkungan yang mempengaruhinya. Pendekatan cognitive dissonance dalam hal ini dapat dijadikan tolak ukur dalam riset perilaku pembelian konsumen yang berfungsi untuk pengemasan pesan iklan persuasif produk atau jasa yang akan ditawarkan oleh pemasar.

Kadang-kadang konsumen sangat terlibat dalam sebuah pembelian namun ia hanya melihat sedikit perbedaan di antara berbagai merek yang ada. Keterlibatan yang tinggi didasari oleh fakta bahwa pembelian tersebut mahal, jarang dilakukan, dan berisiko. Dalam kasus itu, pembeli akan berkeliling untuk mempelajari apa yang tersedia namun akan membeli dengan cukup cepat karena barangkali pembeli sangat peka terhadap faktor harga yang lebih murah atau faktor kenyamanan berbelanja. Setelah pembelian, konsumen mungkin mengalami disonansi/ketidaknyamanan yang muncul setelah merasakan adanya hal-hal yang tidak mengenakkan dari merek yang dibelinya atau setelah mendengar kabar yang menyenangkan mengenai merekmerek lain.

\section{Konsumen yang mengalami} cognitive dissonance menggunakan berbagai strategi dalam upaya untuk mengurangi ketidaknyamanan yang dirasakannya. Mereka berupaya mencari kepastian dan pendapat dari orang lain untuk membenarkan keputusan pembelian yang telah dilakukannya, yaitu dengan cara merendahkan sikap atau pendapat yang mendukung merek yang tidak terpilih; menolak atau menyimpangkan informasi yang tidak mendukung keputusan yang dibuat atau; mencari informasi atau pandangan yang dapat mendukung keputusan yang dibuat. Sumber informasi pendukung yang penting untuk mengatasi cognitive dissonance konsumen adalah iklan. Hal ini sejalan dengan hasil penelitian yang dilakukan Ginting dan Meiyanto mengindikasikan bahwa ketersediaan informasi iklan (penyebaran informasi melalui media cetak dan televisi) yang semuanya itu digolongkan dalam faktor eksternal dari postpurchase dissonance, yang diduga memiliki kontribusi sebesar $91 \%$ sebagai faktor yang memperkuat konsumen melakukan postpurchase dissonance.

Dengan demikian untuk meningkatkan hubungan relevan (relevant) dan mencegah cognition dissonance, yaitu hubungan yang berkaitan antara satu dengan yang lainnya, maka pesan iklan persuasif yang dikemas harus menghindari hubungan penyangkalan (disonan), melainkan hubungan tidak disonan, atau dimana satu kognisi diikuti secara selaras (konsonan).

\section{Kesimpulan}

Pendekatan komunikasi persuasif sangat penting diterapkan pada riset perilaku konsumen terkait dengan 
pengembangan pesan iklan yang mampu memenuhi kebutuhan dan kepuasan konsumen. Dalam melakukan komunikasi persuasif, tentunya pemasar kita harus memahami kriteria tanggung jawab persuasi, sebagaimana yang dikemukakan, yaitu adanya kesempatan yang sama untuk saling mempengaruhi, memberi tahu audiens tentang tujuan persuasi, dan mempertimbangkan kehadiran konsumen. Tujuan analisis komunikasi persusif pada iklan adalah untuk melakukan pengidentifikasian dan pemeriksaan terhadap isi pesan yang terdiri dari tujuan dan konteks sosial dari suatu iklan.

Masalah-masalah komunikasi persuasif periklanan yang dijelaskan pada artikel ini diantaranya isi pesan iklan dan efek serta dampak pesan terebut pada perubahan perilaku pembelian konsumen. Pesan iklan merupakan stimuli yang diterima oleh konsumen melalui komponen sikap yaitu kognitif, afektif, dan konatif yang berkontribusi pada keputusan pembelian produk atau jasa. Agar komunikasi persuasif pada pesan iklan berfungsi dengan baik dan efektif, maka dalam penyampaian pesan-pesan persuasif harus disertai dengan gaya yang mengesankan, menawan, dan tidak membosankan. Bahasa yang digunakan harus mengandung unsur kejelasan, kelugasan dan ketepatan.

Ada tiga pendekatan persuasif yang dapat diaplikasikan, diantaranya Elaboration Likehood Model dikemukakan oleh Petty dan Cacioppo, Atributtion oleh Firtz Heider dan Cognitive Dissonance oleh Festinger. Adapun teori-teori yang termasuk dalam pendekatan komunikasi persuasif lainnya pada studi ilmu komunikasi yang dapat diaplikasikan dalam penelitian mengenai pengiriman dan penerimaan pesan komunikasi pada riset komunikasi pemasaran dan perilaku konsumen diantaranya teori konsistensi kognitif, teori social judgment, teori heuristic processing mode.
Mengingat konsumen cenderung memiliki keterlibatan tinggi dalam pemilihan produk maupun jasa agar sesuai dengan kebutuhannya, maka tidak hanya faktor-faktor komunikasi pemasaran saja yang dilakukan, melainkan pemahaman faktor-faktor eksternal dan internal pengaruh perilaku pembilan perlu dilakukan pemasar dalam merancang komunikasi pemasaran yang efektif. Ketiga pendekatan ini, selain dapat diaplikasikan pada faktor komunikasi pemasaran, dapat juga diaplikasikan pada studi faktor-faktor pengaruh perilaku pembelian konsumen lainnya, meliputi faktor sosial, budaya, dan psikologi.

Saat komunikasi persuasif dilakukan, sebaiknya pemasar tidak disarankan menggunakan data palsu terkait dengan keberadaan produk atau jasa yang ditawarkan, atau yang sengaja dirancang untuk menonjolkan kesan tertentu, dan dibelokkan. Hal tersbut akan mempengaruhi perubahan perilaku konsumen, karena akan terjadi ketidakpercaayaan, ketidakpastian, kecemasan dan ketidakloyalan konsumen dalam melakukan perilaku pembelian produk atau jasa tersebut.

\section{Daftar Pustaka}

Burgon \& Huffner. (2002). Human Communication. London: Sage Publication

Ellyada dan Wiratmojo. (2013). Pengaruh Daya Tarik Brand Ambassador dan Daya Tarik Jingle Iklan Versi Iklan Televisi terhadap Keputusan pembelian Magnum Classic di Kalangan Mahasiswa/i ISI Yogyakarta. Yogyakarta: FISIP Universitas Atmajaya Yogyakarta

Engel, Minniard, dan Engle. (2006). Perilaku Konsumen. Ciputat: Binarupa Aksara

Ginting, Eka Danta Jaya. Sito Meiyanto. (2010). Postpurchase Dissonance Observed from Consumer's 
Intention as an Inovator, Ability as an Opinion Leaders and Level of Creativity. Jurnal Psikologi Volume 37, No.

Hill, E. \& O'esullivan, T. (1999). Marketing. (2nd Edition). New York: Longman.

Kotler, Philip. (2005). Manajamen Pemasaran Jilid 1 dan 2. Jakarta: PT. Indeks Kelompok Gramedia

Loudon, D. L. dan Bitta, A. J. D. (1993) . Consumer behavior, Concepts and Applications. Fouth edition. Singapore: McGraw-Hill

Morrisan. (2010). Periklanan: Komunikasi pemasaran Terpadu.Jakarta: Kencana

Petty, dan Cacioppo. (1996). Attitudes and Persuasion: Classsical and Contemporary Approaches. Colorado: Westview

Stewart, Lea P, dan Brent D. Ruben. (2006). Komunikasi dan Perilaku
Manusia. Edisi Kelima.Jakarta: PT Raja Grafindo Persada

Tubbs, Stewart L dan Sylvia Moss. (1996). Human Communication: Kontekskonteks Komunikasi. Bandung: PT Remaja

Warren J.Keegan, Sandra E.Moriarty, Thomas R Duncan dan Stanly J. Pawiloda. (1995). Marketing. Canada: Prentice Hall

Wibowo, A. S. Elisawati, V., \& Kartajaya, H. (1996). Bermain dengan Persepsi: 36 Kasus Pemasaran Asli Indonesia. Jakarta: PT. Elex Media Komputindo. 